\title{
DEMETRIOS CHOMATIANOS' ACCOUNTS OF THE EARLIEST HISTORY OF BULGARIANS AND THE POSSIBLE ORIGIN OF THREE TOPONYMS FROM THE BULGARIAN NORTHERN BLACK SEA COAST
}

\author{
Stanislava Tsaneva \\ СВЕДЕНИЯТА НА ДИМИТЪР ХОМАТИАН ЗА НАЙ-РАННАТА ИСТОРИЯ \\ НА БЪЛГАРИТЕ И ЕВЕНТУАЛНИЯ ПРОИЗХОД НА ТРИ ТОПОНИМА ОТ \\ БЪЛГАРСКОТО СЕВЕРНО ЧЕРНОМОРИЕ \\ Станислава Цанева
}

\begin{abstract}
This article examines one of the latest and most controversial pieces of information about the origin of the Bulgars. In our attempt to establish its historical credibility, we compared the most important Greek and Old Bulgarian copies of St. Clement of Ohrid's Life, and suggested a date and possible ideological motives behind the creation of so-called „Moesian legend”. Special attention is paid to the coincidence between the names of the modern Bulgarian cities and towns of Varna, Kavarna and Shabla and the toponyms registered in the Hittite inventory inscriptions of the 2nd millennium BCE.
\end{abstract}

Key words: Demetrios Chomatianos, Moesi, Varna, Kavarna, Shabla

DOI: https://doi.org/10.46687/FKPW4819

Резюме: Статията разглежда едно от най-късните и дискусионни сведения за произхода на древните българи. При опита за установяване на историческата му достоверност е направена съпоставка на всички по-важни гръцки и старобългарски преписи на житието, предложени са датировка и възможни идеологически мотиви за създаването на т.нар. „мизийска легенда” u е отделено специилно внимание на съвпадението между имената на съвременните български градове Варна, Каварна и Шабла и топоними, регистрирани в хетски инвентарни надписи от II хил. пр. н. е.

Ключови думи: Димитьр Хоматиан, мизи, Варна, Каварна, Шабла

The Short Life of St. Clement of Ohrid, also called The Ohrid Legend and usually attributed to Archbishop Demetrios Chomatianos (1216 - c. 1236), was published for the first time in a Venetian edition from the beginning of the $18^{\text {th }}$ century and in the Service of the Seven Slavonic apostles of Moscopole of

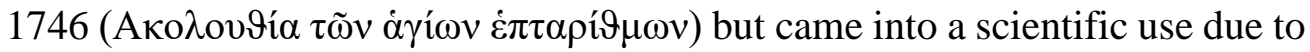
two manuscripts issued respectively by Viktor Grigorovich (Grigorovich 1847: 12-28) and Pavel Šafárik (Šafárik 1853: LVII-LIX) whose works later became 
a basis for new publications and analyzes ${ }^{1}$. In Bulgaria, the Old Greek text along with a parallel Old Bulgarian (Old Church Slavonic) translation was published by Georgi Balaschev (Balaschev 1898: кг-л), Yordan Ivanov (Ivanov 1970: 314-321) and Ivan Duychev (Duychev 1981a: 164-173), and only the Greek one by Alexander Milev (Milev 1966: 174-187).

Demetrios Chomatianos is considered a relatively unreliable source for St. Clement's life. According to the traditional evaluation of the most Bulgarian $20^{\text {th }}$ century medievalists, as historical qualification and literary qualities, he concedes the rank to his predecessor Theophylact of Ohrid (1084-1107) and part of the information he gives about his hagiographic hero seems to be supplemented by assumptions and local legends from the Ohrid region (Ivanov 1970: 315; Duychev 1981a: 164; KME 1995: 458). Probably this is the reason that the Short Life of St. Clement is not present in the corpus Greek sources for the Bulgarian history and has not been a subject of great interest in recent years. As far as we know, the only exception is the monograph of Iliya Iliev (Iliev 2010), which re-evaluates many of the existing outlooks in Bulgarian historiography, but unfortunately has not lead to a breakthrough or a profound scientific discussion. There are also no recent foreign studies on the subject. Günter Prinzing's critical edition deals primarily with the documents of the Ohrid Archbishopric from Chomatianos' time, not with his hagiographic works, as the Life of St. Clement is included among the monuments of dubious authorship (Prinzing 2002: 53* $-54^{*}$ ).

To this rather small scaled literature should be added two more materials that do not follow the popular negative trend. These are an unpublished article by the late Tsanko Tsanev (Tsanev 2004) and the brief commentary in one of Petar Goliyski's books (Goliyski 2006: 257-258). Their content will be discussed in more detail in the course of our presentation. The articles by Emil Georgiev (Georgiev 1975), Petar Koledarov (Koledarov 1983) and Veneta Savova (Savova 2017) will not be taken into consideration because they contain controversial points ${ }^{2}$ or go beyond our problem.

Chomatianos' accounts of the earliest history of Bulgarians are scanty. They occupy only the first paragraph of the Life and in the most popular translation - that by Ivan Duychev, they say:

This great father of ours and enlightener of Bulgaria was by origin of the European Moesi who the ordinary man calls Bulgarians and who were

\footnotetext{
${ }^{1}$ In detail Milev 1966: 167.

${ }^{2}$ See also Iliev 2010: 64.
} 


\section{Годишник на ФХН, XXXII A}

expelled by the Alexander's hand and power from Olympus near Prussa to the North Ocean and the Dead Sea. Many years later, they crossed the Danube with a large army and conquered all neighboring lands: Pannonia and Dalmatia, Thrace and Illyricum, and much of Macedonia and Thessalonica's region (SBL 1986: 395).

Al. Milev's translation is close to Iv. Duychev's regarding the first sentence, but shows some differences in the second one:

They were exiled in the old time by Alexander's military force from the located near Brussa Olympus to the North Ocean and the Dead Sea, and after a long time they crossed the Danube with a terrible army and captured all neighboring areas: Pannonia and Dalmatia, Thrace and Illyricum, and much from Macedonia and Thessaly (Milev 1966: 175).

The differences in both variants are due to the fact that Iv. Duychev follows the Old Bulgarian text of the Life, issued by Y. Ivanov (Ivanov 1970: 316-317), taking into account in good faith all the differences in the available copies in Old Bulgarian and Greek (Duychev 1981a: 167). Regarding the Greek text, all of these scholars prefer P. Šafárik's edition. Y. Ivanov expressly notes that he has a photocopy of the manuscript found by Grigorovich, but prefers to work on Šafárik and Balaschev's copies ${ }^{3}$. Priority of Šafárik is also given by a number of other authors who publish parts or the whole Life in modern Bulgarian translation (Duychev 1981a: 166, note 15).

In the early 1970s, Macedonian scholars M. Georgievski and R. Iljovski published a new manuscript of the Short Life of St. Clement (Georgievski, Iljovski 1974). Despite our efforts, we were not able to get acquainted with the content of their article. It is mentioned in Il. Iliev's monograph (Iliev 2010: 145), but apparently it has not been used in the analysis of the Life. The quotations and the full text of the source are on the Al. Milev's translation (Iliev 2010: 174, 178, 319-322).

The only researcher who criticizes the most commonly used Greek version of the Life is Ts. Tsanev. Taking into account his negative experience of Šafárik's corrections on the text of $О$ писмєнєхь чрвноризца храбра (Tsanev 2002: 6; 2004: 4), he prefers to trust the preserved Old Bulgarian copies and offers the following translation:

This great father of ours and enlightener of Bulgaria was by origin of the Moesian Europi who are also [called] Bulgarians, very reasonable. We

${ }^{3}$ Ivanov 1970: 316 . If we need to be absolutely accurate, the name of Balaschev is not mentioned by him. This is done in a commentary by Iv. Duychev (Duychev 1981a: 167). 
learn that they were originally hurled back by Alexander's hand and order from the Olympic Prussians to the North Ocean and the Dead Sea. In the course of [a] few years, they crossed the Danube with a huge power and came into possession of all countries: Pannonia and Dalmatia, Thrace and Illyricum, and much from the Macedonian and Thessalonica's [land] (Tsanev 2002: 6; 2004: 4).

The strange expression „європїи мисїискыхъ”, which takes the place of

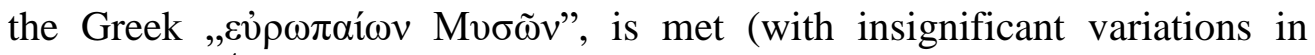
orthography) $)^{4}$ in the both Old Bulgarian copies. The differences in the Slavonic translation of the Life and in Šafárik's edition are commented for the first time by G. Balaschev, who published the Second Ohrid copy (Balaschev 1898: XIII, note 2), and then by Iv. Duychev, who works with the other Slavonic copy the manuscript from the Protaton of Mount Athos (dated 1485) in the 30s and 40 s of the $20^{\text {th }}$ century (Duychev 1981a: 165-169). The presence of the same collocation in copies made in different places and at different times suggests that it is not a question of a copywriting error, but rather a peculiarity of the prime source used by them ${ }^{5}$. And since they are unlikely the copyists to have the same manuscript at hand (unless we assume that it has been transferred from Ohrid to Mount Athos), it remains the possibility of detecting traces of an ancient legend in the Old Bulgarian version, which has subsequently been recast and perhaps reconsidered by Demetrios Chomatianos. Thus, three main problems emerge: 1) which of both collocations is primary, 2) what the first or the second combination might mean, and 3) what is the degree of reliability of the other information in the first paragraph of the Life.

From the point of view of logic, the original expression should still be

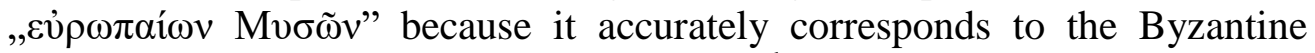
tradition, first registered at the end of the $10^{\text {th }}$ century and widely applied in the following centuries, Bulgarians to be named „Moesi” (Angelov 1971: 340341). This is confirmed by the edition of V. Grigorovich (Grigorovich 1847: 14) - the only author published an authentic medieval Greek copy from the $13^{\text {th }}$ century. ${ }^{6}$ The rest of the manuscripts we have today are late copies of the

\footnotetext{
${ }^{4}$ In Balaschev's edition it is rendered as „Европьї Мй́сїнскьїхь” (Balaschev 1898: XIII, кг).

${ }^{5}$ The most complete retracing of the concepts „Europe” and „Great Europia” in the Middle Bulgarian literary monuments in recent years belongs to V. Gyuzelev, who believes that they arose precisely under the influence of Chomatianos' Life (Gyuzelev 2013: 42-44).

${ }^{6}$ According to Iv. Duychev, the document is stored in the Russian State Library (RSL), f. V. I. Grigorovich, № 818, while Al. Milev points № 1858 in the same collection. We were not able to find which of both numerations is valid.
} 


\section{Годииник на ФХH, XXXII $A$}

$18^{\text {th }}$ and $19^{\text {th }}$ centuries, not all of them being written by specialists-philologists. Šafárik, for example, uses the transcript of prof. Georg Curtius, who is also the author of the parallel Latin translation (Šafárik 1853, LVII), and G. Balaschev - the copies of A. Chakarov for the Old Bulgarian and Bodlev for the Greek text (Balaschev 1898: LVIII, note 1; Milev 1966: 168; Iliev 2010: 145). In principle, work with handwritten copies of medieval documents carries risks of interference and mistakes, but when there is no difference in rendering of the examined expression, the issue can be considered to be solved.

The toponyms and ethnonyms mentioned in the introductory paragraph of the Life are interpreted differently from the modern scholars. According to Al. Milev and A.-E. Tahiaos, for example, Chomatianos speaks about geographical sites in Asia Minor, or because he has mixed the Asia Minor province of Moesia with the Balkan province of the same name, or because he considers Clement a descendant of those Bulgarians whom Byzantium has deported beyond the Bosphorus in the $8^{\text {th }}$ century (SBL 1986: 631, note 2). Il. Iliev accepts Fr. Dvornik's assumption that the evidence is an indirect proof of St. Clement's origin by the Bulgarian Slavs with whom St. Methodius has come into contact during his archonship, and that the mixing of historical epochs, peoples and events reckons an attempt to emphasize the strength and importance of the new settlers who, centuries after, constituted the church diocese of the Ohrid Archbishopric (Iliev 2010: 174). Ts. Tsanev, on the other side, associates the word "Europi" with the name of the Diocletian's Province of Europe (Tsanev 2004: 5). However, it occupies the area from the Maritsa and the Ergene River to the east to the coasts of the Black Sea, the Marmara and the White Sea (Angelov, Kashev, Cholpanov 1983: 63), and does not include parts of Asia Minor at all. It is true that the two historical districts are separated only by the Straits of the Marmara Sea, and that the author of the Life (quite strangely for a man born and grew up close to the objects described) apparently has not been quite aware of the geography of the region because he refers to Moesia the city of Prussa (today Bursa in Turkey), which is a part of the neighboring province of Bithynia, but this can not be a proof positive of the origin of the ethnonym in question, or rather pseudo-ethnonym. Doubts are further reinforced by the fact that in the Old Bulgarian copies the name of Prussa is also transformed into an ethnic name - "Пр४си охимьвїискыє", which does not rest on any historical data.

In fact, the obscurities around the two Moesias - that in Asia Minor and the other on the Balkan Peninsula - are not limited to medieval works. The Moesi are one of the most long-mentioned Thracian tribes - for them spoke ancient authors as Homer, Herodotus, Strabo, Annius Florus (Hom. Il. 2.858; 
13.4-6; 24.278; Hdt. 1.171; 7.74; Strab. 7.3; Flor. Epit. 2.26) and others, but even today there are disputes about whether they are actually Thracian or close to them but a separate ethnic community, what is their direction of migration - from the Balkans to Asia Minor, or vice versa, what is their relationship with the Phrygians called "Mushki" in Assyrian sources, etc. (Georgiev 1977: 182187; Velkov, Venedikov et al. 1979: 119-122; Fol, Spiridonov 1983: 17-20, 43-44, 82-83, 88, 94-95, 98-101, 114; Popov 2009: 25, 35-36; 2011: 29, 45; Mihaylov 2015: 50-56, 60, 63-64). In any case, both Herodotus and Strabo consider the Moesi as migrants from Lydia (Hdt. 7.74.2; Strab. 8.1-4) ${ }^{7}$. According to the latter, the name of the district derives from a Lydian word, which means "beech" and which has been associated with the thick forests, covered the slopes of Mount Olympus in ancient times (Strab. 8.3). It is completely possible for the educated Byzantine writers to have recast this information of the authoritative ancient authors and to have transferred it to their neighboring Bulgarians, combining it with the ancient legend of closing the unholy people behind the Caspian gates (Tapkova-Zaimova 1996: 29-36). Then the entire introductory paragraph should be perceived as part of the propaganda began during Romanos Lakapenos rule $(920$ - 944) and continued in the time of his successors, Bulgarians to be declared former federates settled on the Balkan Peninsula at the will of the Empire (Bozhilov 1995: 61, 72, note 80; Rashev 2001: 147-149).

This assumption has very solid grounds, but it also has one significant disadvantage - it only takes into account the Byzantine viewpoint and does not try to look for an eventual Bulgarian answer. It is unlikely that an ambitious statesman and politician such as Tsar Simeon the Great (893-927) will leave such a challenge without consequences, and in our opinion the preserved Slavonic copies of the Life demonstrate quite well the Bulgarian reaction.

Even a glimpse of the Greek and Old Bulgarian versions reveals that the latter is not a literal translation. Thus, for example, against the Greek: "oü $\varsigma$

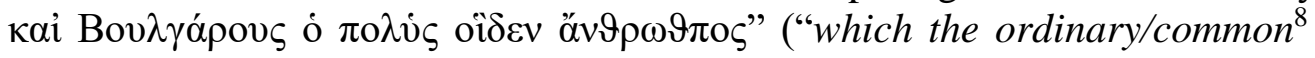
man calls Bulgarians") in the manuscript issued by Y. Ivanov, stands: "ижє и Бльгарїи много разумній" ("who are also [called] Bulgarians, very reasonable”). In the Second Ohrid manuscript, the expression is completed:

\footnotetext{
${ }^{7}$ Strabo also mentions the Thracian hypothesis together with the Lydian one.

${ }^{8}$ Suggested by G. Balaschev according to A. Voronov's translation in the book Glavneyshie istochniki dlya istorii svv. Kirilla i Mefodiya [Главнейшие источники для истории свв. Кирилла и Мефодия], Киев, 1877 (Balaschev 1898: XIII, note 2).
} 


\section{Годишник на ФХН, XXXII A}

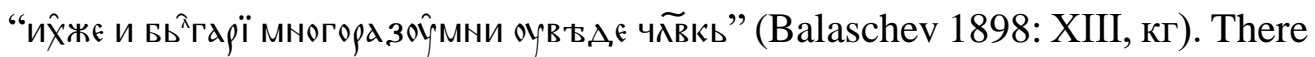
is no sign of suggestion that the use of the name Bulgarians is typical only for the common people.

According to Ts. Tsanev, who adheres mainly to Y. Ivanov's text, the expression "Баьгарїи много разумниїи" is due to the respect of the Byzantine chroniclers to the Bulgars (Tsanev 2004: 5). This thesis contradicts all available sources. On the contrary, the Byzantine political and intellectual elite does not conceal its hostile and disdainful attitude to Bulgaria, no matter before or after baptism, therefore such flattery can not arise outside Bulgarian environment. Even if we accept the view of the good relationship between Demetrios Chomatianos and his non-Greek congregation in the everyday life (Snegarov 1995: 246-252; Iliev 2010: 194-203, 206-218), preserved letters of the Archbishop on church and personal affairs reveal that when his interests were impaired, he easily recalled the cliché of the barbarous inferiority of the local inhabitants (Prinzing 2002: 423-424; Илиев 2010: 188-194, 215-216, $245,264,273-274,310-311$ and in particular note 314, p. 192). Undoubtedly, the range of the "Moesian" conquests, outlined in the Life, which precisely corresponded to the territory of the First Bulgarian Empire during its political apogee, and not to Bulgaria of Asparuh, served well the ambitions of Chomatianos as a quasi-patriarch of the West (Iliev 2010: 100-113), but whether the information in the first paragraph was invented by him or was simply borrowed by an earlier Bulgarian document (or an oral tradition) can not be established yet. It can only be noted that attempts at connecting Bulgarian history to the history of the Old World are not a Byzantine invention. For example, John the Exarch, besides the famous comparison between the Bulgarians and the Khazars, also makes a connection with the genealogy and order of inheritance of the Judaic, Persians and Lydian kings (Yoan Ekzarh 1981: 163); Nominalia (aka List) of the Bulgarian Khans (even without asking the question of its date) is invariably included in the Hellenic and Roman chronicle (Moskov 1988: 18; Kaymakamova 1990: 59-65), and together with it is also marked a distinct trend towards including of Byzantine chronicles in Slavonic literary miscellanies, as the translation of the chronicle of John Malalas is considered the earliest (Kaymakamova 1990: 164-168).

Naturally, connecting the legend for the Bulgarian origin from Asia Minor with the Simeon Age is not the only opportunity. The earliest mention of the name "Moesi" in a Byzantine source belongs to Leo the Deacon (c. 950 - aft. 992), who, although personally involved in part of the military operations of the Empire against Bulgaria, does not hesitate to use archaic concepts not 
only for Bulgarians, but also for other ethnic groups - Russians, Pechenegs, Hungarians. It is difficult to judge whether this is merely a literary style or, as we suspect, here are concealed more serious political motives ${ }^{9}$, but if we assume that the use of the word "Moesi" has started only in the reign of Basil II (976 - 1025), then the Bulgarian response would have occurred during the Age of Tsar Samuel $(986-1014)^{10}$. This would explain the strong emphasis placed on the territorial gains of Bulgarians in the Balkans, the heightened interest in St. Clement, who had taught and preached at Ohrid - a capital in that time, as well as the existence of a "Moesian connection" in another literary monument, also directly related to the deed of Clement - the Second Life of St. Naum of Ohrid.

This work is preserved only in a late copy of the $16^{\text {th }}$ century, which, unfortunately, has probably been destroyed during the World War II (Ivanov 1970: 311; Duychev 1981b: 178; SBL 1986: 527). The idea of St. Naum's "Moesian origin" is comprised still in the first words of the Life: "Съn пр'пп,А, Б'ный и вєликїи шт'ьцъ Nаумъ прозєБъ въ Мии'сїю” (“This reverend and great father of ours grew up in Moesia"), and is further developed by the suggestion that the creators of the Slavonic alphabet had performed missionary activity among the "Moesian and Dalmatian tribes" even before leaving for Great Moravia - "проход,єште и учєште ршд,' мүсїискы и длд'мдтїискыи” (Ivanov 1970: 312; Duychev 1981b: 178; SBL 1986: 81-82). Some scholars are inclined to believe that this Life is written almost entirely under the influence of Greek sources, particularly the Long Life of St. Clement by Theophylact of Ohrid (SBL 1986: 527), but, as it can be seen, it also corresponds to the Bulgarian political doctrine from the $10^{\text {th }}$ - beginning of the $11^{\text {th }}$ century, found its final expression in the "naturalization" of the Holy Brothers in the Short Life of Constantine-Cyril: "Bulgarian by origin, he [St. Cyril - note St. Ts.] was born by pious and devout parents" 11 .

If we put the problem on such a basis, there are two possible ideological suggestions - the Byzantine one, which claims: "You are our former federates, driven out by the great Alexander in the wilderness and accepted by favour in

\footnotetext{
${ }^{9}$ In the $11^{\text {th }}$ and $12^{\text {th }}$ centuries, the fashion of deliberate archaization by Byzantine writers reaches such a degree that sometimes seriously impedes the ethnic identification of the alluded tribes and peoples (Bozhilov, Gyuzelev 2004: 164-166 and in particular note 21).

${ }^{10}$ Samuel's rule is dated according to Ivan Bozhilov's chronology (Bozhilov, Gyuzelev 1999: 318).

${ }^{11}$ This assertion is one of the main arguments that the Life should be assigned to the $13^{\text {th }}$ century, but there are also assumptions of a much earlier date (SBL 1986: 64, 510-511).
} 


\section{Годишник на ФХН, XXXII A}

our lands", and the Bulgarian one, which points out: "We are the descendants of the ancient Moesi, who have given the name of our kingdom, and therefore we possess your former provinces by right." It is another question that "the archbishops of the whole Bulgaria" (i.e. the Archbishopric of Ohrid) in their aspirations for autonomy have chosen to accept and popularize the Bulgarian point of view and have probably developed and enriched it with new details, perhaps even contrary to the content of today's missing local prime sources.

Of course, the ethnic structure of population in Upper and Lower Moesia has been heterogeneous (Mihaylov 2015: 182-193) and searching for a kinship between the ancient tribes and the Bulgarians completely groundless, but that did not seem to worry the creators of these theories. Historical falsifications are not uncommon in the Middle Ages and sometimes play a serious role even in diplomacy and military affairs - let us remind the correspondence of Tsar Kaloyan (1197 - 1207) with Pope Innocent III (1198 - 1216) or the Trojan legend by which the knight Pierre de Bracieux justifies the organization of the Fourth Crusade (Angelov, Georgieva et al. 1982: 135, 182, note 90). In case of accepting Bulgarian origin of the information in the Short Life of St. Clement, however, we should check if it is based on real facts or it is just a political speculation.

Ts. Tsanev regards all the information in the first paragraph of the Life as reliable and connects it with the possible Iranian origin of the Bulgars (Tsanev 2004: 5-6). Even more uncritical is P. Goliyski, who, on the basis of late sources, outright historical counterfeits such as Djagfar Tarihi and Karl Fritzler's speculative theory of "Armenian origin of the Bulgarian-Bavarians", includes the Bulgars in the Cimmerian military-tribal union and even begins its chronological chart for the Bulgarian-Armenian relations with the migrations of the Cimmerians from the $8^{\text {th }}-7^{\text {th }}$ century BCE (Goliyski 2006: 235-264, 597). Of course, such opinions can not be taken seriously. There are no reliable historical accounts of staying of Bulgars in the Asia Minor region in Antiquity, so we will try to find linguistic data for such a connection.

According to Strabo, Moesia in Asia Minor before the Hellenistic period is a contact zone characterized by mixing of Lydian and Phrygian ethnic elements (Strab. 8.3-4) and although he himself is sceptical about this information, today, thanks to archaeological and epigraphic studies, they can be considered credible (Woods, Lloyd et al. 2019). Despite the close and relatively long contacts between Lydia and Phrygia, their population does not belong to the same ethno-linguistic group. The Phrygian language, used during the period $8^{\text {th }}-3^{\text {rd }}$ century BCE, is considered to be related to the Thracian, Illyrian and partly Greek (Mihaylov 2015: 375, note 775; Van den Hout, 
Melchert 2018), while the Lydian language belongs to the family of the Anatolian languages, and in a number of peculiarities occupies an intermediate place between the Hittite and the Luwian language (Houwink ten Cate, Melchert, Van den Hout 2015).

None of the preserved Lydian or Phrygian words have equivalent to the toponymy of medieval or present-day Bulgaria. On the Bulgarian northern Black Sea coast, however, even in nowadays, still exist three names of settlements that closely resemble toponyms in another of the Anatolian languages - the Hittite one.

In his work with the Hittite inventory inscriptions, issued by Silvin Košak (Košak 1982: 308, 310), Bulgarian scientist Nedelcho Nedelchev finds out almost complete coincidence between the names of two Hittite settlements

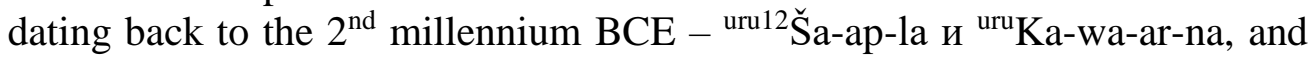
the names of the contemporary Bulgarian towns Shabla and Kavarna. The author does not give an etymological explanation of the concrete toponyms, but explains that the Hittite word "barna", meaning "stone", is also part of the word meaning "water" and implies a relationship with rocks and seashores ${ }^{13}$. Based on this, he believes that the name of the city of Varna, as well as the towns of Shabla and Kavarna, have been acquired in the course of possible Hittite migration from the Balkans to Asia Minor and have survived for so long or thanks to strong local traditions (Nedelchev 2004: 271-272 and in particular 280 , note 26 ) or because they were restored by the Byzantine administration in the $6^{\text {th }}-7^{\text {th }}$ century, immediately before the invasion of the Bulgars in Moesia and Scythia Minor ${ }^{14}$.

This hypothesis (even without broaching the problem of resettlement of the Hittites in Anatolia, which has not yet been resolved) can not be accepted for several reasons. First, during that period, the Byzantine state no longer effectively controls the coastline to the north of the Balkan Mountains. It is true that the barbaric invasions of the $4^{\text {th }}-6^{\text {th }}$ century affect the interior of the peninsula rather than the coast, but the Black Sea cities also suffer serious decline. Secondly, we are not familiar with a case in which Byzantium restores a venerable local name at the expense of its Greek or Latin equivalent. As a rule, the names dating to Greek and Roman Antiquity are rarely replaced and

\footnotetext{
${ }^{12}$ A determinative for a city.

${ }^{13}$ Soviet scientist Leonid Gindin claims that the ancient pre-Greek name of the island of Paros

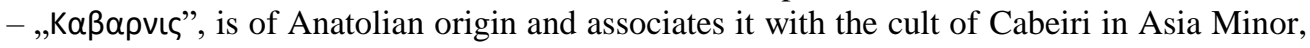
but does not cite any evidence of it (Gindin 1981: 54).

${ }^{14}$ Personal communication with the author during 2003.
} 


\section{Годишник на ФХН, XXXII A}

only if the patron of the respective settlement is a Christian saint or emperor. And last but not least, the phonetic characteristics of the Medieval Greek do not permit proper rendering of names like "šapla". In Byzantine transcription this word would be rendered as ,sapla" or ,savla", which means that the local Bulgarian-Slav population would adopt it in the same distorted form. It seems to us that the foregoing considerations are sufficient to reject the thesis of direct borrowing from Hittite language. The question is whether we could at all prove the Anatolian origin of the given toponyms, and if the answer is affirmative, how did they still reach the Balkans?

The first opportunity, specifically for Shabla, is to look for a Carian connection $^{15}$. The Carian language, known mostly by a large number of bilingual inscriptions of merchants, entered the service in Egypt, also belongs to the Anatolian linguistic family (Melchert 2018) and several asynchronous ancient writers speak of Carian colonization of the North Black Sea coast. However, the reliability of this information is questionable and tends to legendary mythological traditions (Mihaylov 2015: 78-79).

The other option is to think of foreign political and linguistic mediation. We have really good prerequisites for such a hypothesis. Since 546 to 334 BCE Asia Minor is under the domination of the Persian Achaemenid Empire. Despite the widespread ancient clichés of Persian despotism, their presence does not have such a negative effect on the conquered peoples. The Empire imposes a serious military and administrative control over the entire region, but it does not seek a total assimilation of the local population. Regardless of the loss of political independence, as well as the growing Greek cultural influence, during the $6^{\text {th }}-4^{\text {th }}$ century BCE almost all Anatolian languages (except the Hittite and Luwian) are still in use, which is proved by epigraphic materials (Woods, Lloyd et al. 2019). It is tempting to suppose that the words in question have penetrated into the Persian language and, as part of its vocabulary, have finally been acquired by the Bulgars. Such a solution to the problem would fit perfectly into the increasingly popular Iranian hypothesis of their origin, and P. Goliyski, quoting Aram Ter-Gevondyan (Ter-Gevondyan 1977: 19-20), also points to a toponym „Varna” in Upland (Nagorni) Shirvan ${ }^{16}$, claiming that the name derives from the Iranian word „var” - „water” and suffix „na” (Goliyski 2006: 349).

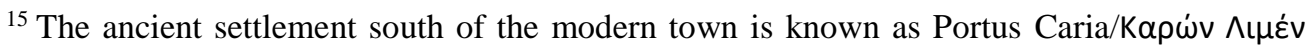
(,Carian Port”).

${ }^{16} \mathrm{~A}$ district in Azerbaijan.
} 
Unfortunately, the reference to Ter-Gevondyan's book is wrong. In the quoted pages there is no mention of a settlement called Varna. They are dedicated to Byzantine-Persian relations during the time of Emperor Heraclius (610 - 641) and the intervention of the Armenian aristocracy in them. Besides, our checks indicated that the words „varna”, „kavarna” и ,ک̌abla” do not exist in modern Persian language (Farsi). Indeed, according to the online dictionary Dehkhoda (https://dictionary.abadis.ir/dehkhoda), there is a word „varna” in Old Persian, but it means ,young”, so coincidence is purely phonetic. The word „šapla" also occurs in modern Persian, but not as a common noun, but as a relatively rare proper name and surname meaning ,young, active, creative, righteous, etc." (https://fa.surnameanalysis.com/Spela-meaning-of-name.amp. html?fbclid=IwAR2-8Lz-B9v311KeidOM0aXgte ugamOoNGWurawtwHp

KWDuvglAh9_-Wno). The used site does not contain any details about its origin $^{17}$.

Our lookup on David MacKenzie's A Concise Pahlavi ${ }^{18}$ Dictionary has proven a bit more successful. There are the words „,bar”, meaning ,sea-shore” or „river-bank”, and „war” - „lake” (MacKenzie 1986: 39, 109), but no matches were found for „kavarna" and „šabla” in any phonetic variants. Everything points to the fact that there can be no question of a permanent including of the examined Anatolian lexis in the Persian language. Rather, there may be some local penetration through migrations of a population from Asia Minor to Armenia and the Caucasus, from where are the earliest reliable data on the emergence of Bulgars ${ }^{19}$.

It is speaking of the well-known history of the Armenian Movses Khorenatsi aka Moses of Chorene (c. 410 - c. 490), who, on the other hand, has borrowed part of his information from the Syrian writer Mar Abbas Katina $\left(4^{\text {th }}\right.$ century CE). Since the main purpose of this chronicle is to present the heroic deeds of the Armenian kings, information about the Bulgars takes up very little of it and is probably quite chronologically confused. Only two short excerpts are quoted in modern Medievistics. The first one is the narrative of King Vaharshak (153 - 131), which mentions that the king turned to the plain lands near the borders of Sharay, called by the ancient Upper Basen. Later

\footnotetext{
${ }^{17}$ According to Mrs. Parisa Rostami, a graduate of Zand University at Shiraz, Iran, to whom we are grateful for the provided links and translation.

${ }^{18}$ The official language of the Sasanian Empire since $3^{\text {rd }}$ to $7^{\text {th }}$ century CE.

${ }^{19}$ The problem of the authenticity of the information in the Brief Latin Chronicle of AD 334 and the Anonymous Roman Chronograph of AD 354 has not yet been finally resolved (Рашев 2001: 9).
} 


\section{Годииник на ФХH, XXXII $A$}

(without specifying the date), these territories were settled by the VgndurBulkar (Bulgars-Unogundurs), led by their chief Vanand-Vund. The second passage concerns the rule of Arshak I (351 - 367), during which the ,, land of the Bulgars" to the north of the Caucasus broke out into riots, forcing many of them to emigrate to the south of Colchis in ,,fruitful and fertile areas" (Petrov, Gyuzelev 1978a: 53).

Movses Khorenatsi's accounts of the Bulgars are accepted inconsistently by historians. There is a predominant opinion that the Armenian chronicler has been confused with the similar names of the rulers and has mistakenly taken the events that took place in the $4^{\text {th }}$ century CE to the $2^{\text {nd }}$ century BCE (Bozhilov, Gyuzelev 1999: 61). One of the few scholars, agreeing with an earlier date, is P. Goliyski again. He suggests a correction in the pronunciation of the ethnonym „Vgndur-Bulkar”, because, in his opinion, it does not correspond to the current Old Armenian pronunciation in the $5^{\text {th }}$ century (Goliyski 2006: 37-50), and the settling of the Bulgars in the district of $\mathrm{Col}$ (later Vanand ) after a series of corrections in the order and duration of the Armenian kings' rule is referred to 186/187 CE (Goliyski 2006: 74-89).

Since we are not specialists in Armenian linguistics, we can not express an opinion about his language analysis. However, considering the author's careless attitude towards the used sources, it is difficult to trust the proposed chronology. It is not supported by cited literature, which does not provide an opportunity for verification and makes its use too risky. The only thing we can say at this stage is that Movses Khorenatsi's information finds confirmation in the Armenian toponymy. Two rivers in the region, where, according to the chronicler, the Bulgars have settled, even today bear the names Vanand-chay and Bulgaru-chay, therefore the credibility of the geographical names is beyond any doubt (Petrov 1981: 95; Bozhilov, Gyuzelev 1999: 61; Rashev 2001: 14). As regards the date, it can only be specified terminus ante quem the second half of the $4^{\text {th }}$ century CE, as without confirmation from other sources there is no possibility of greater accuracy. The problem is that even in the most optimistic variant there is a very long time gap between the extinction of the Anatolian languages (if there is any penetration in the Caucasus area at all) and coming of Bulgars in this region. Our only opportunity in this situation is to turn to the preserved information about the emergence of the three toponyms „Varna”, „Kavarna” and „Shabla” in medieval Bulgaria and to try to make some indirect conclusions.

Undoubtedly, the name Varna is registered earliest in the sources. It is mentioned almost simultaneously in the historical works of Theophanes the Confessor (died 818) and Patriarch Nicephorus (died 829), as well as in 
Chronogrphia tripertita by Anastasius the Librarian (c. 800 - c. 878), based on the chronicles or on the lost prime source of Theophanes and Nicephorus. Talking about the victory of Khan Asparuh over the army of Emperor Constantine IV Pogonatos (668 - 685), all three claim the same thing: that the Bulgars crossed the Danube and persecuted the Romans up to the so-called Varna near (according to Anastasius the Librarian in the environs of Odessos) and the local (according to Patriarch Nicephorus inner) land (Theoph., p. 360; Niceph. 35; Anast. Bibl., p. 227).

It is usually assumed that the word „Varna” is of Slavonic origin. According to the most popular hypothesis, it is formed by metathesis of the noun „vrana” - „crow” (or its homonymous adjective) and denotes some geographical object - perhaps the Provadia River along with the Devnya Lake or the Kamchia River with its tributaries (Petrov 1981: 217-222).

There is indeed a hydronym „Varna" in contemporary Bulgaria. This is the name of a relatively small river in northeastern Bulgaria, which springs away from the village of Tapchileshtovo, Municipality of Omurtag, passes through the town of Targovishte along with its feeder the Siva River and flows into the Golyama Kamchia River not far from the Khan Krum village near town of Shumen (GRB 1980: 118). However, there is no evidence that this name has ever been used for the entire water catchment network of Kamchia. The assumption is based only on the a priori assumption of Slavic domination in the region and the replacement of the old local names with the relevant toponymy. But if we leave for a moment the boundaries of Bulgaria, we will recognize an interesting fact. In the names of almost all medieval Danubian towns and cities under the rule of the Hungarian Kingdom is included the word „var” (Temesvár, Budavar, Zigetvar, etc.) with primary meaning „castle” or "fortress" and secondary "mound" 20 . Today it is no longer in use, but the analogy with the name of many of the Bulgarian revival riverside neighborhoods - „Varosh/a" is remarkable. For the present we have no confirmation that the word has penetrated into Hungarian from the ProtoBulgarian language, which does not mean that this probability is totally excluded $^{21}$. Obviously, the time the Slavs lived in the area of the early medieval

\footnotetext{
${ }^{20}$ Information by Mrs. Anya Sotirov, a former Hungarian language lecturer in Debrecen, Hungary, to whom we owe gratitude for the cooperation.

${ }^{21}$ The word „Var" also exists in the Hun's language. It has been mentioned by Jordanes (Iord. Get. 269), but given the Mommsen's edition (Mommsen 1882), which remains the best so far, it should refer to the lower reaches of the Dnieper River and not be identical to the Hungarian noun (Iordan 1960: 338, note 678).
} 


\section{Годииник на ФХH, XXXII A}

Odessos and generally in the territory of Northeastern Bulgaria was insufficient to impose their local names ${ }^{22}$. It is a well-known fact that local Slavic tribes, the so-called "Seven clans" and the Severi were displaced by Asparuh, respectively, along the borders with Byzantium and the Avarian Khaganate (Theoph., p. 360; Niceph. p. 35). Naturally, Bulgars were settled in their place (Bozhilov, Gyuzelev 2004: 27-28) and their presence seemed to be really tangible, since at the beginning of the $9^{\text {th }}$ century the name "Varna” was already known in Constantinople.

It is more complicated to find what exactly this toponym meant in the $9^{\text {th }}$ century. If we ground on the lexical meaning of the word „,bar/na” in Hittite and Pahlavi, it is most logical to assume this is a geographical object, for example, a particular part or the entire Bay of Varna, which has undergone significant changes as a result of transgressions and anthropogenic activity (Peev 2008: 250-280). The use of the word ,var” in medieval Hungarian, however, argues rather in favour of the assumption that it is alluded a fortress - either that of Odessos itself, or some temporary fortification near the city. Unfortunately, available sources do not allow any clarification. The results of archaeological excavations show that at the end of the $7^{\text {th }}$ century the fortress of Odessos was demolished and the place remained unsettled until the $8^{\text {th }}-9^{\text {th }}$ century, when some small pagan settlements were created a few kilometers from the sea (Rashev 1997: 34). In this case, it can not even be determined whether during this period the word „varna” is used as a name of a specific settlement or simply as a common noun, which later narrowed its meaning only to a particular object.

The situation with the names of the towns Shabla and Kavarna is even more complicated. Specifically for Kavarna, there are disputes whether this is initially a name of a settlement or of the whole district known in the sources as „Land of Karvuna”. Yet, the arguments in favour of the second opinion has recently prevailed (Bozhilov, Gyuzelev 2004: 380-381; Pletnyov 2018: 21-32). It is also unclear if under this name (assuming that from the beginning it refers to a fortress rather than a district ${ }^{23}$ ) was always meant the town near contemporary Kavarna. The scholar's opinions are mostly hesitating between Balchik, on whose territory an early Proto-Bulgarian settlement existed, and the medieval Karvuna on the cape Chirakman, as even the preferences of the authors of the latest History of Dobrudja, v. 2 seem to differ (Bozhilov,

\footnotetext{
${ }^{22}$ Iv. Duychev takes the opposite view (Duychev 1972a: 70).

${ }^{23} \mathrm{P}$. Georgiev's idea that it could derive from the Proto-Bulgarian language with the meaning of ,the land of the hundred fortresses” (Georgiev 2002: 70-82) is not well proved.
} 
Gyuzelev 2004: 26, 32, 305, 381).

It is determined with certainty that the earliest mentions in the medieval sources are not of a fortress, but of a district. In Bulgarian historical science, it is accepted that the expression „зємля Карвоунскад” appears for the first time in so-called Bulgarian Apocryphal Chronicle (Bozhilov, Gyuzelev 2004: 27$28,379-381)-$ a literary monument dated to the middle or the end of the $11^{\text {th }}$ century (Duychev 1972b: 126, 129-130; SBL 1983: 360-361; Kaymakamova 1990: 27-28, 124-132). In the last few years however, Hristo Trendafilov challenged the date of the chronicle and on the basis of textual similarities with Mauro Orbini's historical work Kingdom of the Slavs (Orbini 2012), the collection Book for Various Occasions of 1572 by Jacob Kraykov and the apocryphal apocalyptic works of the Priest Vasiliy Dragol's codex (aka Dragolov sbornik), declared it a late work from the beginning of the $17^{\text {th }}$ century (Trendafilov 2016). In this case, the earliest use of the expression should be in the Dubrovnik Charter of Tsar Ivan II Asen of 1230, which lists in details a large part of the districts (choras) of his kingdom, including „Карв४нскал хора" (Petrov, Gyuzelev 1978b: 205; Bozhilov, Gyuzelev 2004: 379-380; Pletnyov 2018: 22-23). The geographical denomination Carbona/K $\alpha \rho \beta o v v v \alpha$ as a name of a town, situated between Kaliakra and Varna, is registered only after the first quarter of the $14^{\text {th }}$ century. Later, a variety of other forms appeared, such as Cavarna, Gavarna, Karnava, etc., which listing would load the text unduly (Bozhilov, Gyuzelev 2004: 380). From the available data, it can not be ascertained whether the name was in use during the First Bulgarian Empire, although, according to Iv. Bozhilov, this is very likely (Bozhilov, Gyuzelev 2004: 21).

The problem is to a certain extent etymological. According to the official position of Bulgarian historians and linguists, the name „Karvuna”

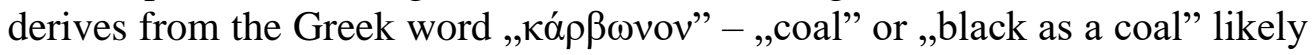
(Bozhilov, Gyuzelev 2004: 21, 381) - an explanation that would correspond to the situation in Inner Dobrudja with its black soils, but not to the white rocks on which Balchik, the medieval fortress on Chirakman and most of the towns along the Bulgarian Black Sea coast were built. In our opinion, in this case it is really possible to face with metathesis. The initial form was probably Kavarna, as a derivative of Varna with unclear meaning. It seems that as early as the $9^{\text {th }}$ century the name was spread over the territory of an administrative district, controlled by a fortress with today's uncertain location, and during the Byzantine rule it was transformed into „Karvuna”. It is possible that this transformation has been carried out under the influence of the newly settled Greek population, which may also imply an interference of folk etymology. Of 


\section{Годииник на ФХH, XXXII $A$}

course, the backward transition - adopting of the name „Carbona/Karvuna” by the Asparuh's Bulgars and its convergence with a word in their language should not be ignored. In this case, the transfer should be from the interior of Dobrudja to the administrative center on the Black Sea coast of that time, but in the current state of the sources the question should be left open. The third alternative - to face with an influence by Balchik's oldest name - Krounoi, seems completely impossible.

On the other hand, the name "Shabla" does not appear in documents from the times of the First and the Second Bulgarian Empire. Indeed, on or near the territory of the contemporary town there should have been a Bulgar military post or port, because in the local Turkish cemetery Sal-Mush is found a military inventory inscription in Greek (Beshevliev 1992: 193-195), but other traces of the activities of the possible garrison are not preserved. We do not intend to discuss Omeljan Pritsak's analysis of the place of the bagatur bagains in the Proto-Bulgarian rank hierarchy here. The conclusions of it are summarized by Iv. Bozhilov (Bozhilov, Gyuzelev 2004: 42-43). The more important thing for us is that there is no information how long this settlement existed and how exactly it was called. In the sea charts of the $14^{\text {th }}-15^{\text {th }}$ century, on the cape bearing the same name, is marked the insignificant port of Laxilutico (Bozhilov, Gyuzelev 2004: 282). A parallel use of a Bulgarian name is possible, such as the situation was with other seaports as ObluchitsaIsaccea (today in Romania) and Belgrad-Maurocastro-Akkerman (today the city of Belgorod-Dnestrovskyi/ Bilhorod-Dnistrovskyi in Ukraine), but for the present it is unprovable. The allegation in the popular site Wikipedia that the name "Shabla" derives from the Proto-Bulgarian word „shabala" meaning „ladle” (https://bg.wikipedia.org/wiki/\%D0\%A8\%D0\%B0\%D0\%B1\%D0\% $\mathrm{BB} \% \mathrm{D} 0 \% \mathrm{~B} 0$ ) is a local patriot's invention without the slightest historical or linguistic grounds.

We could not find confirmation of the often promoted version that the old name of the local lighthouse „Shabla fener" means „Sand lighthouse” and is at the root of naming the village. This toponym is not included in Vasil Mikov's compendious study (Mikov 1943), although more than 25,000 local names from different parts of Bulgaria are preserved in his private card-index, all noted down in result of his field work (Kovachev 1996: 66). There are also no good modern publications on that subject, and the last volume of the Bulgarian etymological dictionary, which should cover the letters after the Cyrillic „ $\Phi ”$, is still in preparation. There are also no traces of such common nouns or adjectives in the Bulgarian literature of the $19^{\text {th }}-20^{\text {th }}$ century (RRODD 1974). In any case, the word ,shabla" is not inherited by the Old 
Turkic and does not exist in modern Turkish ${ }^{24}$, it is unknown even in the colloquial speech. The closest matches we could find were „șab"/“șap" „young, youth" (here a parallel with the fore-mentioned personal name and surname „Šapla” could be made) and ,șaplak” - ,slap in the face” (TRS 1977: $801,804)$, as naming of the village on the second one looks completely unlikely. However, without access to appropriate dictionaries from the Ottoman-Turkish period and support from good specialists, we can not reach more definite conclusions. The only curious detail is that the name of Shabla has not been changed in no one renaming from the first half of the $20^{\text {th }}$ century, although this is a consistent policy regarding the Turkish names of settlements and that the measure is applied to all other villages in the municipality ${ }^{25}$.

In conclusion, we can say the following. The accounts from the introductory paragraph of the Short Life of St. Clement of Ohrid by Demetrios Chomatianos can not be accepted as a reliable source for the earliest Bulgarian history. They are a reflection of the popular falsification created by the Byzantine writers after the middle of the $10^{\text {th }}$ century and propagated more or less actively until the $15^{\text {th }}$ century, and even if there are traces of the Bulgarian political doctrine in them (which is not categorically proven), they have no any informative value. Their coincidence with the two Hittite toponyms from Asia Minor, to which we could add Varna, is accidental and direct influence of the Anatolian languages on the Proto-Bulgarian lexis is completely excluded. Nevertheless, the etymological relation of the name "Varna" and a seashore or a fortification, located near the water, is very likely because it finds confirmation in the languages of Sasanian Iran and the medieval Hungarian Kingdom, with which the Bulgars have had contacts at different stages of their history. The problem with the name of Kavarna (the medieval Karvuna) needs further clarification, as there is a possibility of transferring both from the Asparuh Bulgars to the local population and vice versa. Regarding Shabla, the opinion that this is an already extinct Ottoman-Turkish word outweighed all the rest, but this problem is within the competence of the respective Ottoman specialists.

\footnotetext{
${ }^{24}$ Our lookups in Bulgarian-Turkish dictionaries offer the same option - „kum” for „,sand” and „kumlu” for „sandy” (see for example BTR 1992: 459).

${ }^{25}$ Official historical reference to Village Municipal Administration - village of Shabla (Dobrich State Archive, F. 75K), published in Archives State Agency Information System (ASAIS).
} 


\section{Годииник на ФХH, XXXII A}

\section{REFERENCES}

Angelov 1971: Angelov, D. Obrazuvane na balgarskata narodnost. Sofia: Nauka i izkustvo [Ангелов, Д. Образуване на българската народност. София: Наука и изкуство].

Angelov, Georgieva et al. 1982: Angelov, D., S. Georgieva, V. Gyuzelev, L. Yonchev, Str. Lishev, P. Petrov, B. Primov, P. Tivchev, G. Tsankova-Petkova. Istoriya na Balgaria. T. 3. Vtora balgarska darzhava. Sofia: BAN [Ангелов, Д., С. Георгиева, В. Гюзелев, Л. Йончев, Стр. Лишев, П. Петров, Б. Примов, П. Тивчев, Г. Цанкова-Петкова. История на България. Т. 3. Втора българска държава. София: БАН].

Angelov, Kashev, Cholpanov 1983: Angelov, D., St. Kashev, B. Cholpanov. Balgarska voenna istoriya. Ot Antichnostta do vtorara chetvart na X v. Sofia: BAN [Ангелов, Д., Кашев, Ст., Чолпанов, Б. Българска военна история. От Античността до втората четвърт на Х в. София: БАН].

Balaschev 1898: Balaschev, G. Kliment, episkop Slovenski, i Sluzhbata mu po star slovenski prevod s edna chast gratski paralelen tekst. Sofia: Darzhavna pechatnitsa [Баласчев, Г. Климент, епископ Словенски, и Службата му по стар словенски превод с една част гръцки паралелен текст. София: Държавна печатница].

Beshevliev 1992: Beshevliev, V. Parvobalgarski nadpisi. Sofia: BAN [Бешевлиев, В. Първобългарски надписи. София: БАН].

BTR 1992: Balgaro-turski rechnik. Sofia: BAN [Българо-турски речник. София: БAH].

Bozhilov 1995: Bozhilov, Iv. Sedem etyuda po Srednovekovna istoria. Sofia: Anubis [Божилов, Ив. Седем етюда по Средновековна история. София: Анубис].

Bozhilov, Gyuzelev 1999: Bozhilov, Iv., V. Gyuzelev. Istoriya na Srednovekovna Balgaria (VII - XIV vek). T. I. Sofia: Anubis [Божилов, Ив., В. Гюзелев. История на Средновековна България (VII-XIV век). Т. I. София: Анубис].

Bozhilov, Gyuzelev 2004: Bozhilov, Iv., V. Gyuzelev. Istoriya na Dobrudza. T. 2. Srednovekovie. Veliko Tarnovo: Faber [Божилов, Ив., В. Гюзелев. История на Добруджа. Т. 2. Средновековие. Велико Търново: Фабер].

Dehkhoda Dictionary: 〈https://dictionary.abadis.ir/dehkhoda (status 11.05.2019)>.

Duychev 1972a: Duychev, Iv. Obedinenieto na slavyanskite plemena v Miziya prez VII v. - V: Balgarsko Srednovekovie. Prouchvaniya varhu politicheskata i kulturnata istoriya na Srednovekovna Balgaria. Sofia: Nauka i izkustvo, 7086 [Дуйчев, Ив. Обединението на славянските племена в Мизия през VII в. - В: Българско Средновековие. Проучвания върху политическата и културната история на Средновековна България. София: Наука и изкуство, 70-86].

Duychev 1972b: Duychev, Iv. Edno legendarno svedenie za Asparuh. - V: Balgarsko Srednovekovie. Prouchvaniya varhu politicheskata i kulturnata istoriya na 
Srednovekovna Balgaria. Sofia: Nauka i izkustvo, 122-133 [Дуйчев, Ив. Едно легендарно сведение за Аспарух. - В: Българско Средновековие. Проучвания върху политическата и културната история на Средновековна България. София: Наука и изкуство, 122-133].

Duychev 1981a: Duychev, Iv. Kratkoto Klimentovo zhitie ot Dimitriy Homatian. V: Prouchvaniya varhu srednovekovnata balgarska istoriya i kultura. Sofia: Nauka i izkustvo, 164-173 [Дуйчев, Ив. Краткото Климентово житие от Димитрий Хоматиан. - В: Проучвания върху средновековната българска история и култура. София: Наука и изкуство, 164-173].

Duychev 1981b: Duychev, Iv. Prostranno gratsko zhitie i sluzhba na Naum Ohridski. . - V: Prouchvaniya varhu srednovekovnata balgarska istoriya i kultura. Sofia: Nauka i izkustvo, 174-192 [Дуйчев, Ив. Пространно гръцко житие и служба на Наум Охридски. - В: Проучвания върху средновековната българска история и култура. София: Наука и изкуство, 174-192].

Fol, Spiridonov 1983: Fol, Al., T. Spiridonov. Istoricheska geografiya na trakiyskite plemena do III pr. n. e. Sofia: BAN [Фол, Ал., Т. Спиридонов Историческа география на тракийските племена до III в. пр. н. е. София: БАН].

Georgiev 1975: Georgiev, E. Kratkoto zhitie na Kliment Ohridski v novo osvetlenie. // Literaturna misal, 19, № 4, 102-110 [Георгиев, Е. Краткото житие на Климент Охридски в ново осветление // Литературна мисъл, 19, № 4, 102-110].

Georgiev 2002: Georgiev, P. Imeto Karvuna i prabalgarite. // PalaeobulgaricaStarobalgaristika, XXVI, 2, 70-82 [Георгиев, П. Името Карвуна и прабългарите. // Palaeobulgarica-Старобългаристика, XXVI, 2, 70-82].

Georgiev 1977: Georgiev, Vl. Trakite i tehniyat ezik. Sofia: ВAN [Георгиев, Вл. Траките и техният език. София: БАН].

Georgievski, Iljovski 1974: Georgievski, M., R. Iljovski. Novootkrien rakopis so kratkoto zhitie na Kliment Ohridski. - V: Glasnik na institutot za natsionalna istorija, 2. Skopie, 237-249 [Георгиевски, М., Р. Илјовски Новооткриен ракопис со краткото житие на Климент Охридски. - В: Гласник на инстутот за национална историја, 2. Скопие, 237-249].

Gindin 1981: Gindin, L. A. Drevneyshaya onomastika vostochnych Balkan. (Frakohetto-luviyskye i frako-maloaziyskie izoglossy). Sofia: BAN [Гиндин, Л. А. Древнейшая ономастика Восточных Балкан. (Фрако-хетто-лувийские и фрако-малоазийские изоглоссы). София: БАН].

Goliyski 2006: Goliyski, P. Balgarite v Kvkaz i Armenia (II - X vek). Sofia: Tangra TanNakRa [Голийски, П. Българите в Кавказ и Армения (II - X век). София: ТАНГРА ТанНакРа].

GRB 1980: Geografski rechnik na Balgaria. Sofia: Nauka i izkustvo [Географски речник на България. София: Наука и изкуство].

Grigorovich 1847: Grigorovich,V. I. Izyskaniya o slavyanskih apostolah, proizvedennye v stranah Evropeyskoy Turtsii // Zhurnal Ministerstva narodnogo prosveshteniya, ch. 53. Sankt-Peterburg, 1-29 [Григорович, В. И. 


\section{Годишник на ФХH, XXXII}

Изыскания о славянских апостолах, произведенные в странах Европейской Турции. // Журнал Министерства народного просвещения, ч. 53. Санкт-Петербург, 1-29].

Gyuzelev 2013: Gyuzelev, V. Apologiya na Srednovekovieto. Vtoro dopalneno izdanie. - V: Sachineniya v 5 toma. T. 1. Sofia: Izdatelstvo „Zahariy Stoyanov“, 17-224 [Гюзелев, В. Апология на Средновековието. Второ допълнено издание. - В: Съчинения в 5 тома. Т. 1. София: Издателство „Захарий Стоянов”, 17-224].

Houwink ten Cate, Melchert, Van den Hout 2015: Houwink ten Cate, Ph. H. J., H. C. Melchert, Th. P. J. Van den Hout. Anatolian languages. - Encyclopedia Britannica, 20.05.2015 <https://www.britannica.com/topic/Anatolianlanguages (status 24.05.2021)>

Iliev 2010: Iliev, Il. Ohridskiyat arhiepiskop Dimitar Homatian i balgarite. Sofia: Anubis [Илиев, Ил. Охридският епископ Димитър Хоматиан и българите. София: Анубис].

Iordan 1960: Iordan. O proishozhdenii i deyaniyah getov. Getica. Vstupitelynaya statya, perevod, kommentariy E. Ch. Skrzhinskoy. Moskva: Izdatelystvo vostochnoy literatury [Иордан. О происхождении и деяниях гетов. Getica. Вступительная статья, перевод, комментарий Е. Ч. Скржинской. Москва: Издательство восточной литературы].

Ivanov 1970: Ivanov, Y. Balgarski starini iz Makedoniya. Vtoro fototipno izdanie. Sofia: Nauka i izkustvo [Иванов, Й. Български старини из Македония. Второ фототипно издание. София: Наука и изкуство].

Kaymakamova 1990: Kaymakamova, M. Balgarska srednovekovna istoriopis. Sofia: Nauka i izkustvo [Каймакамова, М. Българска средновековна историопис. София: Наука и изкуство].

KME 1995: Kirilo-Metodievska entsiklopediya. T. II (I - O). Sofia: Universitetsko izdatelstvo „Sv. Kliment Ohridski“ [Кирило-Методиевска енциклопедия. T. II (И - О). София: Университетско издателство „Св. Климент Охридски"].

Koledarov 1983: Koledarov, P. Koga i zashto Dimitar Homatian e napisal Kratkoto zhitie na Kliment Ohridski? // Literaturna misal, 27, № 3, 89-100 [Коледаров, П. Кога и защо Димитьр Хоматиан е написал Краткото житие на Климент Охридски? // Литературна мисъл, 27, № 3, 89-100].

Košak 1982: Košak, S. Hittite Inventory Texts (CTH 241 - 250). Heidelberg: Carl Winter Universitätsverlag.

Kovachev 1996: Kovachev, N. Edna obobshtavashta kniga po toponimiya na arheologa Vasil Mikov Valov. - V: Sastoyanie i problemi na balgarskata onomastika. T. 3. Onomasti i onomastichni izsledvaniya v Balgaria. Veliko Tarnovo: Universitetsko izdatelstvo „Sv. Sv. Kiril i Metodiy“, 65-68 [Ковачев, Н. Една обобщаваща книга по топонимия на археолога Васил Миков Вълов. - В: Състояние и проблеми на българската ономастика. Т. 
3. Ономасти и ономастични изследвания в България. Велико Търново: ]Университетско издателство „Св. Св. Кирил и Методий”, 65-68].

MacKenzie 1986: MacKenzie, D. N. A Concise Pahlavi Dictionary. London: Oxford University Press.

Melchert 2018: Melchert, H. C. Carian language. - Encyclopedia Britannica, 13.03.2018<https://www.britannica.com/topic/Carian-language (status 24.05.2021)>

Mihaylov 2015: Mihaylov, G. Vtoro dopalneno i preraboteno izdanie. Sofia: Izdatelstvo na Nov balgarski universitet [Михайлов, Г. Траките. Второ допълнено и преработено издание. София: Издателство на Нов български университет].

Mikov 1943: Mikov, V. Proizhod i znachenie na imenata na nashite gradove, sela, reki, planini i mesta. Sofia: Pechatnitsa Hr. G. Danov [Миков, В. Произход и значение на имената на нашите градове, села, реки, планини и места. София: Печатница Хр. Г. Данов].

Milev 1966: Milev, Al. Gratskite zhitiya na Kliment Ohridski. Sofia: BAN [Милев, Ал. Гръцките жития на Климент Охридски. София: БАН].

Mommsen 1882: Mommsen, Th. Iordanis Romana et Getica, recensuit Th. Mommsen. // MGH, V 1, AA, 1-200. Berolini.

Moskov 1988: Moskov, M. Imennik na balgarskite hanove. (Novo talkuvane). Sofia: Darzhavno izdatelstvo „D-r Peter Beron“ [Москов, М. Именник на българските ханове. (Ново тълкуване). София: Държавно издателство ,Д-р Петър Берон”].

Nedelchev 2004: Nedelchev, N. Proizhodat na svetskata tsarska institutsiya v Drevniya Preden iztok prez III - II hil. pr. n.e. Shumen: Universitetsko izdatelstvo „Episkop Konstantin Preslavski““ [Неделчев, Н. Произходът на светската царска институция в Древния Преден изток през III - II хил. пр. н.е. Шумен: Университетско издателство „Епископ Константин Преславски"].

Orbini 2012: Orbini, M. Tsarstvoto na slavyanite. Istoriya ot Don Mavro Orbini ot Raguza. Prevod ot staroitaianski Simeon Todorov, Elitsa Popova. Sofia: Damyan Yakov [Орбини, М. Царството на славяните. История от Дон Мавро Орбини от Рагуза. Превод от староиталиански Симеон Тодоров, Елица Попова. София: Дамян Яков].

Peev 2008: Peev, P. Fizikogeografsko opisanie na Varnenskiya zaliv i ezerata. - V: Pletnyov, V. (red.). Varna prez Srednovekovieto. Ch. 1: Ot VII do kraya na X v. Varna: Zograf, 250-280 [Пеев, П. Физикогеографско описание на Варненския залив и езерата. - В: Плетньов, В. (ред.) Варна през Средновековието. Ч. 1: От VII до края на Х век. (Варна: Зограф, 250-280].

Petrov 1981: Petrov, P. Obrazuvane na Balgarskata darzhava. Sofia: Nauka i izkustvo [Петров, П. Образуване на Българската държава. София: Наука и изкуство].

Petrov, Gyuzelev 1978a: Petrov, P., V. Gyuzelev. Hristomatiya po istoriya na 


\section{Годииник на ФХH, XXXII $A$}

Balgaria. T. I. Sofia: Nauka i izkustvo [Петров, П., В. Гюзелев. Христоматия по история на България. Т. I. София: Наука и изкуство].

Petrov, Gyuzelev 1978b: Petrov, P., V. Gyuzelev. Hristomatiya po istoriya na Balgaria. T. II. Sofia: Nauka i izkustvo [Петров, П., В. Гюзелев. Христоматия по история на България. Т. II. София: Наука и изкуство].

Pletnyov 2018: Pletnyov, V. Gradat Karvuna? (Izvori i arheologiya). - V: Prinosi kam balgarskata arheologiya. T. VIII. Sofia: BAN, 21-32 [Плетньов, В. Градът Карвуна? (Извори и археология). - В: Приноси към българската археология. Т. VIII. София: БАН, 21-32].

Popov 2009: Popov, D. Drevna Trakia. Istoriya i kultura. Sofia: LIK [Попов, Д. Древна Тракия. История и култура. София: ЛИК].

Popov 2011: Popov, D.Traki. Istoricheski i kulturen obzor. Sofia: Iztok-Zapad [Попов, Д. Траки. Исторически и културен обзор. София: Изток-Запад].

Prinzing, 2002: Demetrii Chomateni ponemata diaphora. Recensuit Günter Prinzing (Berolini et Novi Eboraci) $=$ Corpus fontium historiae Byzantinae. Volumen XXXVIII. Series Berolinensis. Berlin \& New York: Walter de Gruyter.

RRODD 1974: Rechnik na pedki, ostareli i dialektni dumi v litereturara ni ot XIX i XX vek. Sofia: BAN [Речник на редки, остарели и диалектни думи в литературата ни от XIX и XX век. София: БАН].

Rashev 1997: Rashev, R. Severozapadniyat chernomorski bryag prez rannoto Srednovekovie. - V: Balgarite v Severnoto Prichernomorie. Izsledvaniya i materiali. T. 6. Veliko Tarnovo: Universitetsko izdatelstvo „Sv. Sv. Kiril i Metodiy“, 33-44 [Рашев, Р. Северозападният черноморски бряг през ранното Средновековие. - В: Българите в Северното Причерноморие. Изследвания и материали. Т. 6. Велико Търново: Университетско издателство „Св. Св. Кирил и Методий”, 33-44].

Rashev 2001: Rashev, R. Prabalgarite i Balgarskoto hanstvo na Dunav. Sofia: Klasika i stil [Рашев, Р. Прабългарите и Българското ханство на Дунав. София: Класика и стил].

Šafárik 1853: Šafárik, P. J. Památky hlaholského písemnictví. Prague: Bohumila Haase.

Savova 2017: Savova, V. Homatiyanoviyat kanon za sv. Kliment Ohridski na 1-i glas. // Kulturni mostove. Minalo i savremie. Godishnik na Sofiyskiya universitet, Tsentar za slavyano-vizantiyski prouhvaniya "Ivan Duychev", t. 99 (18), 507 518 [Савова, В. Хоматиановият канон за св. Климент Охридски на 1-и глас. // Културни мостове. Минало и съвремие. Годишник на Софийския университет, Център за славяно-византийски проучвания „Иван Дуйчев”, т. 99 (18), 507-518].

SBL 1983: Stara balgarska literatura. T. 3. Istoricheski sachineniya. Sastavitelstvo i redaktsiya Iv. Bozhilov. Sofia: Balgarski pisatel [Стара българска литература. Т. 3. Исторически съчинения. Съставителство и редакция Ив. Божилов. София: Български писател]. 


\section{Stanislava Tsaneva. Demetrios Chomatianos'...}

SBL 1986: Stara balgarska literatura. T. 4. Zhitiepisni tvorbi. Sastavitelstvo i redaktsiya Kl. Ivanova. Sofia: Balgarski pisatel [Стара българска литература. Т. 4. Житиеписни творби. Съставителство и редакция Кл. Иванова. София: Български писател].

Shabla (Wikipedia) [Шабла (Уикипедия)]: <https://bg.wikipedia. org/wiki/\%D0\%A8\%D0\%B0\%D0\%B1\%D0\%BB\%D0\%B0 (status 22.05.2021)>.

Snegarov 1995: Snegarov, Iv. Istoriya na Ohridskata arhiepiskopiya. T. 1. Ot osnovavaneto y do zavladyavaneto na Balkanskiya poluostrov ot turtsite. Vtoro fototipno izdanie. Sofia: Akademichno izdatelstvo „Prof. Marin Drinov“ [Снегаров, Ив. История на Охридската архиепископия. T. 1. От основаването ѝ до завладяването на Балканския полуостров от турците. Второ фототипно издание. София: Академично издателство „Проф. Марин Дринов”].

Surnameanalysis (Šapla): <https://fa.surnameanalysis.com/Spela-meaning-ofname.amp.html?fbclid=Iw AR2-8Lz-

B9v31lKeidOM0aXgte_ugamOoNGWurawtwHpKWDuvglAh9_-Wno (status 27.05.2021)>

Tapkova-Zaimova 1996: Tapkova-Zaimova, V. Srednovekovni predstavi za narodite otvad Dunav. - V: Balgarite v Severnoto Prichernomorie. Izsledvaniya i materiali. T. 5. Veliko Tarnovo: Universitetsko izdatelstvo „Sv. Sv. Kiril i Metodiy“, 29-36 [Тъпкова-Заимова, В. Средновековни представи за народите отвъд Дунав. - В: Българите в Северното Причерноморие. Изследвания и материали. Т.5. Велико Търново: Университетско издателство „Св. Св. Кирил и Методий”, 29-36].

Ter-Gevondyan 1977: Ter-Gevondyan, A. N. Armenia i Arabskiy halifat. Erevan: AN Armyanskoy SSR [Tер-Гевондян, A. Н. Армения и Арабский халифат. Ереван: АН Армянской ССР].

Trendafilov 2016: Trendafilov, Hr. Balgarskiyat apokrifen letopis i Mavro Orbini. Shumen: Regionalna biblioteka "Stiliyan Chilingirov" [Трендафилов, Хр. Българският апокрифен летопис и Мавро Орбини. Шумен: Регионална библиотека „Стилиян Чилингиров”].

TRS 1977: Turetsko-russkiy slovary. Moskva: Russkiy yazyk [Турецко-русский словарь. Москва: Русский язык].

Tsanev 2002: Tsanev. Ts. "Za bukvite”. Novi aspecti. Shumen: Antos [Цанев, Ц. ,За буквите”. Нови аспекти. Шумен: Антос].

Tsanev 2004: Tsanev. Ts. Sv. Kliment Ohridski i balgarskata tsarkva. Lyublin (nepublikuvan material). [Цанев, Ц. Св. Климент Охридски и българската църква. Люблин (непубликуван материал)].

Van den Hout, Melchert 2018: Van den Hout, Th. P. J.q Melchert, H. C. Phrygian language. - Encyclopedia Britannica, 01.06.2018 < https://www.britannica. com/topic/Phrygian-language (status 24.05.2021) >.

Velkov, Venedikov et al. 1979: Velkov, Iv., Iv. Venedikov, V1. Georgiev, G. 


\section{Годииник на ФХH, XXXII A}

Georgiev, T. Gerasimov, Hr. Danov, R. Katincharov, T. Ivanov, Iv. Marazov, G. Mihaylov, Vl. Popov, M. Stancheva, G. Toncheva, V. Tapkova-Zaimova, M. Chichikova, Al. Fol. Istoriya na Balgaria. T. 1. Parvobitnoobshtinen i robovladelski story. Traki. Sofia: BAN [Велков, Ив., Ив. Венедиков, Вл. Георгиев, Г. Георгиев, Т. Герасимов, Хр. Данов, Р. Катинчаров, Т. Иванов, Ив. Маразов, Г. Михайлов, Вл. Попов, М. Станчева, Г. Тончева, В. Тъпкова-Заимова, М. Чичикова, Ал. Фол. История на България. Т. 1. Първобитнообщинен и робовладелски строй. Траки. София: БАН].

Woods, Lloyd et al. 2019: Woods, J. E., S. H. F. Lloyd, D. P. M. Collon, D. F. Easton, J. F. Haldon, Ph. H. J. Houwink ten Cate. Anatolia. History, Map \& Fact. Encyclopedia Britannica, 01.08.2019 < https://www.britannica. com/place/Anatolia (status 11.11.2019)>.

Yoan Ekzarh 1981: Yoan Ekzarh. Shestodnev. Prevod ot starobalgarski, posleslov i komentar Nikolay Tsv. Kochev. Sofia: Nauka i izkustvo [Йоан Екзарх. Шестоднев. Превод от старобългарски, послеслов и коментар Николай Цв. Кочев. София: Наука и изкуство]. 